\title{
The timing of pupping and molting of the Pacific harbor seal, Phoca vitulina richardii, at Punta Banda Estuary, Baja California, Mexico
}

\section{Temporalidad de los nacimientos y de la muda de la foca de puerto, Phoca vitulina richardii, en el estero de Punta Banda, Baja California, México}

\author{
Eva María Fernández-Martín ${ }^{1}$, Gisela Heckel ${ }^{1 *}$, Yolanda Schramm², \\ María Concepción García-Aguilar ${ }^{1}$ \\ ${ }^{1}$ Centro de Investigación Científica y de Educación Superior de Ensenada (CICESE), \\ Carretera Ensenada-Tijuana No. 3918, Zona Playitas, 22860 Ensenada, Baja California, México. \\ ${ }^{2}$ Universidad Autónoma de Baja California, Carretera Transpeninsular Ensenada-Tijuana No. 3917, \\ Fraccionamiento Playitas, 22860 Ensenada, Baja California, México. \\ * Corresponding author. E-mail: gheckel@cicese.mx
}

\begin{abstract}
Pupping and molting of Phoca vitulina are processes that occur each year with high precision, although their timing varies according to location. Knowledge about the timing of these events allows us to determine when the highest numbers of individuals are hauled out, which is important to achieve a good abundance estimation. In this study we determined the timing of pupping and molting of $P$. $v$. richardii at Punta Banda Estuary, Baja California (Mexico), previously unknown at this site or along its entire distribution in Mexico. Observations were carried out during the 2011 and 2012 pupping seasons, as well as the 2012 molting season. We determined that the pupping season starts in midFebruary and ends in mid-April, and that the maximum number of pups occurs in mid-March. The late premolt stage was observed from the end of March to the beginning of July, with the peak proportion of individuals in this stage at the beginning of May. The molting period extends from the end of April to mid-July, with the peak proportion of individuals molting at the beginning of June. The reverse molt pattern (starting on the torso and ending on the head and flippers) was the most common. The highest number of adult and subadult individuals on land was observed during the molting season; therefore, the best time to carry out counts to estimate seal abundance in this area is from the beginning of May to the beginning of June.
\end{abstract}

Key words: abundance, timing, pupping, molting, Phoca vitulina richardii.

RESUMEN. Los nacimientos y la muda de Phoca vitulina son procesos anuales que se repiten con alta precisión en el tiempo, aunque éste varía dependiendo del lugar. El conocimiento de la temporalidad de estos eventos permite determinar en qué momento se encuentra el mayor número de individuos en tierra, lo cual es importante para obtener una estimación más precisa de la abundancia de esta especie. En este trabajo se determinó la temporalidad de los nacimientos y la muda de P. v. richardii en el estero de Punta Banda, Baja California, que se desconocía hasta ahora, ahí y en toda su distribución en México. Se realizaron observaciones durante la temporada de cría de 2011 y 2012 , y durante la temporada de muda de 2012. Se determinó que la temporada de cría comenzó a mediados de febrero y finalizó a mediados de abril, y que el máximo número de crías ocurrió a mediados de marzo. La etapa tardía de premuda se presentó desde finales de marzo hasta principios de julio, y la máxima proporción de individuos en esta etapa se observó a principios de mayo. El periodo de muda ocurrió desde finales de abril hasta mediados de julio, y la máxima proporción de individuos en muda se observó a principios de junio. El patrón de muda inverso (empieza por el tronco y termina en la cabeza y las aletas) fue el más común. El mayor número de individuos adultos e inmaduros en tierra se encontró durante la temporada de muda, de manera que el periodo más recomendable para realizar conteos, con el fin de estimar la abundancia de focas en la zona, es de principios de mayo a principios de junio.

Palabras clave: abundancia, temporalidad, crías, muda, Phoca vitulina richardii.

\section{INTRODUCTION}

The distribution of the Pacific harbor seal, Phoca vitulina richardii, extends from Japan to Mexico (Committee on Taxonomy 2016). In Mexico, this species is found along the west coast of the Baja California Peninsula, on 9 islands between Coronado and Asunción islands (Maravilla-Chávez and Lowry 1996, Lubinsky-Jinich in press). It is a philopatric species (Härkönen and Harding 2001) as the seals do not undertake seasonal migrations (Stewart and Yochem 1994)

\section{INTRODUCCIÓN}

La foca de puerto del Pacífico, Phoca vitulina richardii, se distribuye desde Japón hasta México (Committee on Taxonomy 2016). En México, se encuentra en 9 islas sobre la costa occidental de Baja California, desde las islas Coronado hasta isla Asunción (Maravilla-Chávez y Lowry 1996, Lubinsky-Jinich en prensa). Es una especie filopátrica (Härkönen y Harding 2001), que no realiza migraciones estacionales (Stewart y Yochem 1994), y se alimenta en un radio 
and feed within a radius of 2 to $30 \mathrm{~km}$ from their haul-out sites (Suryan and Harvey 1998, Tollit et al. 1998). Pupping and molting of harbor seals are annual processes controlled by biotic and abiotic factors (Bigg 1981) and thus occur with high temporal precision (Temte 1991).

The timing of pupping and molting of harbor seals varies according to the geographic location of the colonies. Pupping is mainly controlled by photoperiod (Temte 1994). Temte et al. (1991) reported 3 birth timing patterns for P. v. richardii: (1) a latitudinal cline, from south to north, pupping occurring first in San Quintín Bay, Baja California, Mexico, and lastly in Grays Harbor, Washington, USA; (2) in Puget Sound, Washington, pupping occurs approximately 2 months later than at other sites at the same latitude; and (3) from northern British Columbia to Alaska pupping does not show any latitudinal variation. For example, on Tugidak Island, Alaska, the pupping season begins in May (Jemison and Kelly 2001). In Puget Sound, Washington, it begins in August (Newby 1973), whereas on San Jose Island, Washington, it begins in June (Suryan 1995). In San Francisco, California, it begins in March (Bohorquez 2001), but in the Southern California Bight in February (Stewart and Yochem 1994). In Mexico, where scant studies have been conducted, pups have been observed between January and April (Padilla-Villavicencio 1990, Loya-Salinas et al. 1992, Lubinsky-Jinich in press).

The molting season occurs between the pupping season and 2 to 3 months after (Bigg 1981). The factors that can influence this process are photoperiod, temperature, and hormones (Ling 1972, Ashwell-Erickson et al. 1986, Mo et al. 2000); therefore, the timing of the molt depends on the sex, age, and stage of sexual maturity of each individual (Thompson and Rothery 1987, Daniel et al. 2003). The molting phenology of $P$. $v$. richardii has only been studied on Tugidak Island, where molting occurs from July to September (Daniel et al. 2003). In Mexico, throughout its distribution, individuals undergoing the molt have been observed from March to June (Lubinsky-Jinich in press).

Haul-out sites are used more frequently during the pupping season because females give birth and nurse their pups on land, and males remain on land for a longer period of time to mate after the pups have been weaned (Bonnes et al. 2006). They are also used during the molting period, when seals spend more time resting (Daniel et al. 2003). As a result of this behavior, the number of seals on land varies seasonally (Brown and Mate 1983, Jemison and Kelly 2001, Daniel et al. 2003). To estimate the size of the colonies it is thus necessary to know when pupping and molting occur and determine during which of these events the highest number of individuals congregate on land, since this also varies among sites (Huber et al. 2001, Jemison et al. 2006).

Information on the biology and ecology of the harbor seal in Mexico is scarce. The timing of pupping and molting are not known and it is possible that in the abundance surveys undertaken to date (e.g., Padilla-Villavicencio 1990, LoyaSalinas et al. 1992, Lubinsky-Jinich in press), the counts may de 2 a $30 \mathrm{~km}$ alrededor de las zonas terrestres de descanso (Suryan y Harvey 1998, Tollit et al. 1998). Los nacimientos y la muda de la foca de puerto son procesos anuales que se repiten con alta precisión temporal (Temte 1991), ya que se encuentran controlados por factores bióticos y abióticos (Bigg 1981).

La temporalidad de los nacimientos y de la muda de la foca de puerto varía en función de la localización geográfica de las colonias. Los nacimientos están controlados principalmente por el fotoperiodo (Temte 1994). Temte et al. (1991) describieron 3 patrones para la temporalidad de los nacimientos de P. v. richardii: (1) una clina latitudinal, de sur a norte, en la cual los nacimientos suceden primero en bahía San Quintín, Baja California, México, y por último en Grays Harbor, Washington, EUA; (2) en Puget Sound, Washington, los nacimientos suceden aproximadamente 2 meses después que en lugares de la misma latitud; y (3) del norte de Columbia Británica a Alaska los nacimientos no presentan ninguna variación latitudinal. Por ejemplo, en la isla Tugidak, Alaska, los nacimientos comienzan en mayo (Jemison y Kelly 2001); en el sur de Puget Sound, Washington, en agosto (Newby 1973); en la isla San José, Washington, en junio (Suryan 1995); en la bahía de San Francisco, California, en marzo (Bohorquez 2001); y en las islas del Canal, California, en febrero (Stewart y Yochem 1994). Para México, sólo hay registros de crías en momentos puntuales entre enero y abril (Padilla-Villavicencio 1990, Loya-Salinas et al. 1992, Lubinsky-Jinich en prensa).

La temporada de muda sucede entre la temporada de cría y de 2 a 3 meses después de ésta (Bigg 1981). Los factores que pueden influir en este proceso son el fotoperiodo, la temperatura y las hormonas (Ling 1972, Ashwell-Erickson et al. 1986, Mo et al. 2000); por lo tanto, el momento en el que muda cada individuo depende de su sexo, edad y estado de madurez sexual (Thompson y Rothery 1987, Daniel et al. 2003). La fenología de la muda de P. v. richardii sólo ha sido estudiada en la isla Tugidak, donde la muda ocurre de julio a septiembre (Daniel et al. 2003). En México, se han observado individuos mudando entre marzo y junio a lo largo de su distribución (Lubinsky-Jinich en prensa).

Las zonas de descanso son utilizadas con mayor frecuencia durante la temporada de cría, ya que en estos lugares las hembras paren y alimentan a sus crías, y los machos permanecen más tiempo en tierra para aparearse después del destete (Bonnes et al. 2006). También son utilizadas durante la temporada de muda, cuando las focas pasan más tiempo descansando (Daniel et al. 2003). Debido a este comportamiento, existe una variación temporal en la abundancia de focas en tierra (Brown y Mate 1983, Jemison y Kelly 2001, Daniel et al. 2003). Por lo tanto, para evaluar el tamaño de las colonias es necesario conocer la temporalidad de los nacimientos y la muda, y determinar en cuál de estos eventos se congrega el mayor número de individuos en tierra, ya que esto también varía entre localidades (Huber et al. 2001, Jemison et al. 2006). 
not have been conducted at the appropriate time and the size of the population may be underestimated. The objective of this study was to determine the timing of pupping and molting, and characterize both processes, of $P$. v. richardii at Punta Banda Estuary (PBE), Baja California, near the northernmost part of its distribution range in Mexico.

\section{MATERIALS AND METHODS}

\section{Field work}

PBE $\left(31^{\circ} 42^{\prime}-31^{\circ} 47^{\prime} \mathrm{N}, 116^{\circ} 37^{\prime}-116^{\circ} 40^{\prime} \mathrm{W}\right)$ is located in the northwestern part of the Baja California Peninsula, in the southwestern part of Todos Santos Bay (Fig. 1). It is a coastal lagoon environment representative of the Californian ecoregion and has been designated a Wetland of International Importance (Ramsar Site no. 1604).

The field work was conducted from February to April 2011 and from January to July 2012. Land-based observations were made once a week in 2011 and 3 times a week in 2012, preferably during low tide when typically more individuals are hauled out (Jemison and Kelly 2001). A total of 11 counts were performed in 2011 and 77 in 2012.
El conocimiento sobre la biología y ecología de la foca de puerto en México es escaso. Se desconoce la temporalidad de los nacimientos y de la muda, por lo que es posible que para las estimaciones de abundancia realizadas hasta ahora (e.g., Padilla-Villavicencio 1990, Loya-Salinas et al. 1992, Lubinsky-Jinich en prensa), los conteos no se hayan efectuado en las fechas adecuadas y el tamaño de la población podría estar subestimado. El objetivo de este estudio fue caracterizar y determinar la temporalidad de los nacimientos y la muda de P. v. richardii en el estero de Punta Banda (EPB), Baja California, localizado cerca del extremo norte de la distribución de la especie en México.

\section{MATERIALES Y MÉTODOS}

\section{Trabajo de campo}

El EPB $\left(31^{\circ} 42^{\prime}-31^{\circ} 47^{\prime} \mathrm{N}, 116^{\circ} 37^{\prime}-116^{\circ} 40^{\prime} \mathrm{W}\right)$ se localiza en el noroeste de la península de Baja California, en la zona suroeste de la bahía de Todos Santos (Fig.1). Es un ambiente costero lagunar representativo de la ecorregión californiana, y se ha declarado como un Humedal de Importancia Internacional (sitio RAMSAR no. 1604).

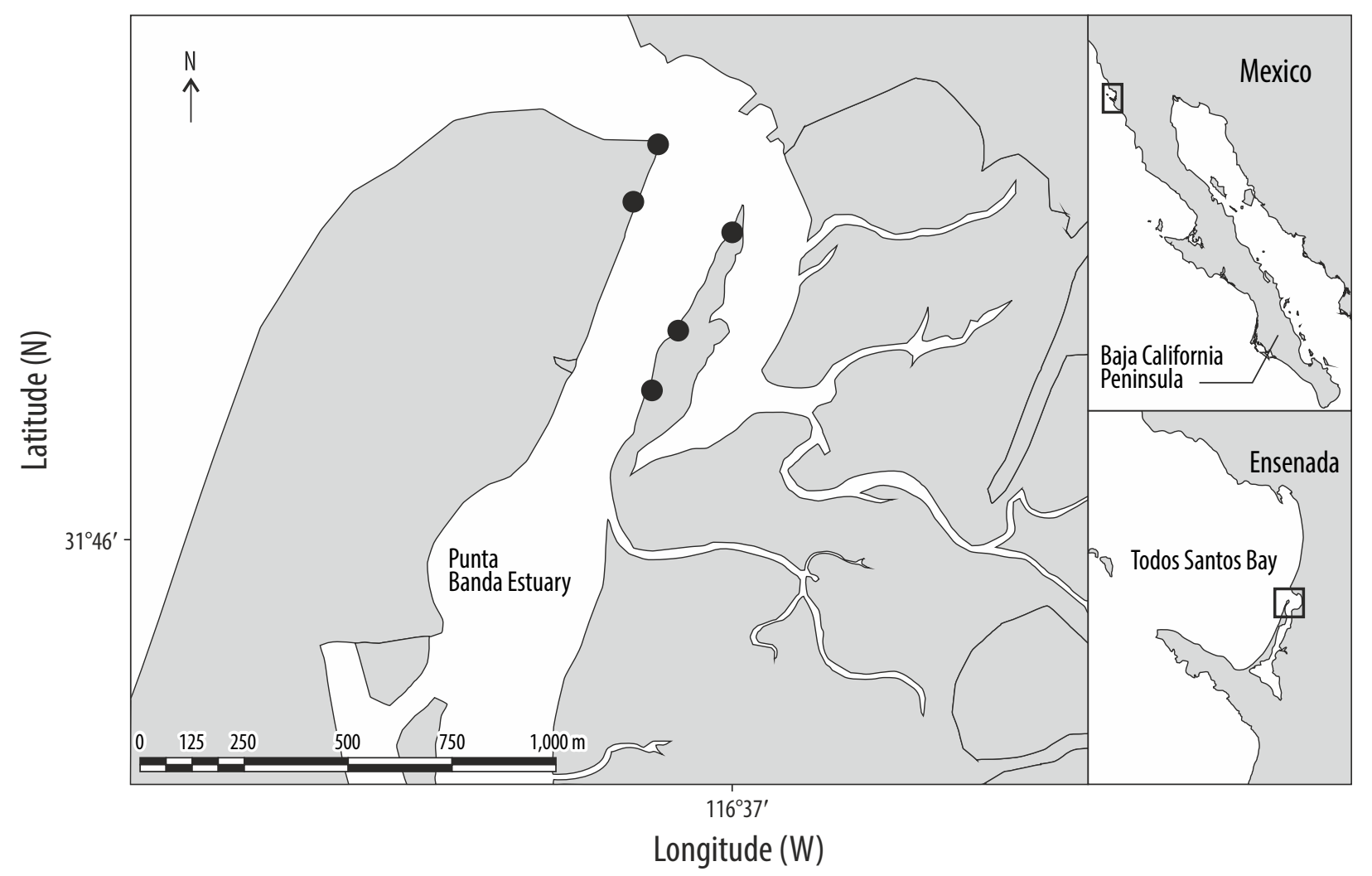

Figure 1. Mouth of Punta Banda Estuary, Baja California, Mexico. Sites where the harbor seal (Phoca vitulina richardii) colony is usually found $(\bullet)$.

Figura 1. Boca del estero de Punta Banda, Baja California, México. Sitios donde suele localizarse la colonia de focas de puerto (Phoca vitulina richardii) (•). 
Observations were made using binoculars $(7 \times 50)$, a telescope $(25 \times)$, and a digital camera with telephoto zoom lens (200-400 mm).

To determine the timing of pupping, during each count we recorded the total number of individuals on land and in the water at the mouth of PBE (Fig. 1), as well as the number of pups, which are easily distinguished by their new pelage and the small size of their heads. The individuals born during the sampling year and not yet weaned were categorized as pups. Solitary pups that did not interact with an adult during the observation hours were categorized as weaned pups.

The molting process was characterized based on the molt stages described by Daniel et al. (2003), in particular the late premolt stage (premolt C), because it was the stage that could be identified unequivocally, and the molt stages, which in the present study were grouped into one single stage. The pelage of animals in premolt $\mathrm{C}$ is a uniform tan or brown color and has lost the spots and rings (Daniel et al. 2003). During the molt, the new, shinier hair slowly replaces the old hair until the whole body is covered. The individuals that could not be classified into one of these stages (premolt or molt) were categorized as "undetermined". We also recorded the progression of the molt, that is, the part of the body where the process begins and how the shedding of old hair progresses over the body (Daniel et al. 2003). The most commonly recognized molt pattern (Stutz 1967, Ashwell-Erickson et al. 1986, Daniel et al. 2003) is characterized by the appearance of new hair first on the head and flippers and then on the torso. The reverse pattern is characterized by the appearance of new hair first on the torso and lastly on the head and flippers (Daniel et al. 2003).

\section{Data analysis}

The model described by Rothery and McCann (1987) was used to determine the timing of pupping. The model has been successfully used to describe the temporal distribution of elephant seal (Mirounga sp.) females and pups on land (Rothery and McCann 1987, García-Aguilar 2004). The model assumes that the temporal distribution of pups follows a normal distribution, with a mean pupping date, $\mu$ (in days), and standard deviation, $\sigma$, and that the nursing period, $L$, is the same for all the pups. The number of pups at time $t$, $n(t)$ (days), is given by:

$$
n(t)=N_{T} \cdot p\left(t, \mu_{i}, \sigma_{i}, L\right)
$$

where $N_{T}$ is the total number of pups born in a single season and $p\left(t, \mu_{i}, \sigma_{i}, L\right)$ is the proportion of pups expected at time $t$. For both years studied, $t=1$ and corresponds to 1 January. This proportion considers all the pups born before time $t$ minus those that were weaned before $t-L$; hence, the normal proportion of $p$ is:
El trabajo de campo se realizó de febrero a abril de 2011 y de enero a julio de 2012. Se hicieron observaciones desde tierra una vez por semana en 2011 y 3 veces por semana en 2012, en marea baja preferentemente, ya que es cuando más individuos se observan en tierra (Jemison y Kelly 2001). Se realizaron un total de 11 conteos en 2011 y 77 en 2012. Para las observaciones se utilizaron binoculares $(7 \times 50)$, un telescopio $(25 \times)$ y una cámara fotográfica digital con lente zoom telefoto (200-400 $\mathrm{mm})$.

Para determinar la temporalidad de los nacimientos, en cada conteo se registró el número total de individuos en tierra y en agua, dentro de la boca del EPB (Fig. 1), así como el número de crías, que se distinguen fácilmente por el pelaje nuevo y el pequeño tamaño de su cabeza. Se consideraron crías a los individuos nacidos el año del muestreo y que aún no eran destetados. Cuando una cría se encontraba sola durante las horas de observación, sin ninguna relación con un animal adulto, se le clasificó como cría destetada.

Para caracterizar el proceso de muda se registró el número de individuos que se encontraban en las etapas descritas por Daniel et al. (2003), específicamente la etapa tardía de premuda (premuda $\mathrm{C}$ ), porque fue la etapa que se podía identificar inequívocamente, y las etapas de la muda, que en este estudio se agruparon en una sola etapa. Los animales en premuda $\mathrm{C}$ se caracterizan por haber perdido las manchas $\mathrm{y}$ los anillos, y por presentar un pelaje café oscuro o claro uniforme (Daniel et al. 2003). En cambio, durante la muda el pelo nuevo, más brilloso y definido, va reemplazando poco a poco al pelo viejo hasta cubrir el cuerpo del animal. Los individuos que no se pudieron clasificar en alguna de estas etapas se registraron como "no determinable". Además, se registró el número de individuos que presentaban cada patrón de progresión de la muda, que depende de la región del cuerpo donde inicia el proceso y cómo éste se va extendiendo a lo largo del cuerpo (Daniel et al. 2003). El patrón de muda más descrito (Stutz 1967, Ashwell-Erickson et al. 1986, Daniel et al. 2003) se caracteriza por la presencia inicial de pelo nuevo en la cabeza y las aletas. El patrón de muda inverso se caracteriza por la presencia de pelo nuevo inicialmente en el tronco y por último en la cabeza y las aletas (Daniel et al. 2003).

\section{Análisis de los datos}

Se utilizó el modelo de Rothery y McCann (1987) para determinar la temporalidad de los nacimientos. El modelo ha sido empleado exitosamente para describir la distribución temporal de hembras y crías del elefante marino (Mirounga sp.) en tierra (Rothery y McCann 1987, García-Aguilar 2004). El modelo supone que la distribución temporal de las crías sigue una distribución normal con una fecha media de nacimientos $\mu$ (en días) y desviación estándar $\sigma$, y que la duración de la lactancia, $L$, es igual para todas las crías. El número de crías en el tiempo $t, n(t)$ (días), está dado por: 


$$
p\left(t, \mu_{i}, \sigma_{i}, L\right)=\phi\left(\frac{t-\mu_{i}}{\sigma_{i}}\right)-\phi\left(\frac{t-L-\mu_{i}}{\sigma_{i}}\right)
$$

where $\phi$ is the cumulative distribution of the standard normal distribution. This equation describes a symmetric curve around $t=\mu+L / 2$, the moment when the maximum number of pups occurs. $N_{T}$ is the value of the slope obtained after performing linear regression between $p\left(t, \mu_{i}, \sigma_{i}, L\right)$ and the number of observed pups (Rothery and McCann 1987). The values of $\mu_{i}, \sigma_{i}$, and $L$ were obtained by minimizing the sum of squares of the residual variation between the model and the 2012 data. As there were fewer data for the 2011 analysis, the duration of the nursing period estimated for 2012 was used to estimate $\mu$ and $\sigma$.

To determine molt timing and progression, the premolt $\mathrm{C}$ and molt data collected in 2012 were used. We calculated the relative cumulative frequency of the number of individuals in each of these stages and the data were fit to a nonlinear logistic model. The start and end dates of each stage were defined as when the proportion of individuals was $>0.01$ and $>0.99$, respectively. To identify the period with the highest proportion of individuals in the premolt $\mathrm{C}$ stage and molt stage, a polynomial regression was done using the Origin 8.5.1 and Curve Expert Professional 1.6.3 programs. To determine the predominant molting pattern and if there were significant differences between the percentage of individuals that presented each pattern, a Mann-Whitney $U$ test (Zar 2010) was performed, using a significance level $(\alpha)$ of 0.05 and STATISTICA 7.1.

To determine whether a greater number of individuals haul out during the pupping or the molting season, the percentage of the colony found on land was calculated for each count. A minimum colony size of 99 individuals was used because it was the maximum count recorded. A time series was generated of the total number of individuals and of adult and immature individuals. Because of the wide fluctuation of the data, a 14-unit moving average was obtained to analyze their trend and be able to determine during which season more than $50 \%$ of the colony was on land. The analysis was performed using STATISTICA 7.1.

\section{RESULTS}

\section{Timing of pupping of harbor seal}

The temporal distribution of the harbor seal pups showed a regular pattern (Fig. 2), which was satisfactorily described by the model $\left(R^{2}=0.991\right.$ in 2011 and $R^{2}=0.887$ in 2012). Based on the 2012 data, nursing lasted 22.65 days. In both years (2011 and 2012), the pupping season lasted approximately 9 weeks, from mid-February to mid-April (Table 1, Fig. 2). The mean pupping date occurred in early March and the maximum number of pups occurred in mid-March

$$
n(t)=N_{T} \cdot p\left(t, \mu_{i}, \sigma_{i}, L\right)
$$

donde $N_{T}$ es el número total de crías producidas en una sola temporada y $p\left(t, \mu_{i}, \sigma_{i}, L\right)$ es la proporción esperada de crías al tiempo $t$. Para ambos años estudiados $t=1 \mathrm{y}$ corresponde al 1 de enero. Esta proporción considera a todas las crías que nacieron antes del tiempo $t$ menos las que fueron destetadas antes de $t-L$, por lo que la distribución normal de $p$ es:

$$
p\left(t, \mu_{i}, \sigma_{i}, L\right)=\phi\left(\frac{t-\mu_{i}}{\sigma_{i}}\right)-\phi\left(\frac{t-L-\mu_{i}}{\sigma_{i}}\right)
$$

donde $\phi$ es la distribución acumulada de la distribución normal estandarizada. Esta ecuación describe una curva simétrica alrededor de $t=\mu+L / 2$, el momento en el que ocurre el máximo número de crías. $N_{T}$ es el valor de la pendiente que se obtiene al hacer la regresión lineal entre $p\left(t, \mu_{i}, \sigma_{i}, L\right)$ y el número de crías observadas (Rothery y McCann 1987). Los valores de $\mu_{i}, \sigma_{i}$ y $L$ se obtuvieron al minimizar la suma de cuadrados de la variación residual entre el modelo y los datos observados en 2012; para el análisis de 2011, al haber menos datos, se empleó la duración de la lactancia estimada en 2012 para estimar $\mu$ y $\sigma$.

Para determinar la temporalidad de la muda, se utilizaron los datos de las etapas premuda $\mathrm{C}$ y muda recolectados en 2012. Se calculó la frecuencia acumulada relativa del número de individuos en cada una de estas etapas y se realizó un ajuste no lineal del modelo logístico. Para cada etapa, se consideró como la fecha de inicio cuando la proporción de individuos fue $>0.01 \mathrm{y}$ el final cuando la proporción fue $>0.99$. Para identificar el periodo con mayor proporción de individuos en la etapa de premuda $\mathrm{C}$ y en la etapa de muda, se realizó una regresión polinomial utilizando los programas Origin 8.5.1. y Curve Expert Professional 1.6.3. Para determinar si existían diferencias significativas entre el porcentaje de individuos que presentaba cada patrón de progresión de la muda, y cuál fue el patrón predominante, se empleó una prueba $U$ de Mann-Whitney (Zar 2010). Ésta se realizó con un nivel de significancia $(\alpha)$ de 0.05 utilizando el programa STATISTICA 7.1.

Para determinar en qué temporada se pueden encontrar más individuos en tierra, se calculó para cada conteo el porcentaje de la colonia que se encontraba en tierra. Para ello, se empleó como tamaño mínimo de la colonia 99 individuos, ya que fue el máximo conteo registrado. De esta forma se generó una serie de tiempo del número total de individuos y de los individuos adultos e inmaduros. Debido a la gran fluctuación de los datos, se obtuvo la media móvil de 14 términos para ver la tendencia de éstos y poder determinar cuál es la temporada en la que se puede ver más del $50 \%$ de la colonia en tierra. El análisis se realizó con el programa STATISTICA 7.1. 
(Table 1, Fig. 2). The total number of pups estimated was 34 in 2011 and 35 in 2012 (see linear regressions in Fig. 2).

\section{Timing and progression of the molt of harbor seals}

The temporal distribution of the cumulative relative frequency of the number of individuals in the premolt $\mathrm{C}$ and molt stages showed a satisfactory fit to the model $\left(R^{2}=0.995\right.$ for premolt $\mathrm{C}$ and $R^{2}=0.998$ for the molt stage) (Fig. 3). The premolt $\mathrm{C}$ stage lasted 15 weeks, from March to early July (Table 2). The molt stage lasted approximately 11 weeks, from late April to mid-July. The temporal distribution of the proportion of individuals in the premolt $\mathrm{C}$ and molt stages was fit with a fifth-degree polynomial and a third-degree polynomial, respectively $\left(R^{2}=0.803\right.$ for premolt $\mathrm{C}$ and $R^{2}=0.737$ for the molt stage). The peak proportion of individuals in premolt $\mathrm{C}$ occurred on 5 May $(63 \%)$ and in the molt stage, on 10 June (48\%).

Significant differences were found between the 2 molt patterns $(U=37, P<0.001)$. Of the individuals that could be classified per day, on average $19 \%$ showed that the head and flippers were the first areas to shed and $81 \%$ showed the reverse molt pattern, the head and flippers being the last areas to shed.

\section{Temporal variation in the abundance of harbor seals on land}

During the pupping and molting seasons, more than $50 \%$ of the total number of individuals were hauled out. In the case of adult and immature individuals, only during the molting season were more than $50 \%$ observed on land (Fig. 4).

\section{Discussion}

\section{Timing of pupping of harbor seals}

The pupping season of P. v. richardii in PBE lasted from mid-February to mid-April. Punctual observations of pups have been made in the study area during this period of time in 1983, 1984, and 1990 (Padilla-Villavicencio 1990, LoyaSalinas et al. 1992). The mean pupping date estimated for the 2011 and 2012 seasons varied by one day, reflecting the high synchronization of the annual reproductive cycle of harbor seals in specific areas (Temte 1991). Padilla-Villavicencio (1990), however, recorded 13 pups in early May 1982 at PBE. These pups may have been weaned pups or the pupping season may have been delayed because of environmental conditions, such as reduced food availability the year before the survey was conducted (Bohorquez 2001, Jemison and Kelly 2001). The latter hypothesis is less likely because in 1981 the values of the Oceanic Niño Index did not indicate any anomalies (CPC 2015). Two pups were also observed in late January 1984 (Padilla-Villavicencio 1990), but they may have been premature pups.

\section{RESUltados}

\section{Temporalidad de los nacimientos de focas de puerto}

La distribución temporal de las crías de foca de puerto presentó un patrón regular (Fig. 2), que fue satisfactoriamente descrito por el modelo $\left(R^{2}=0.991\right.$ en 2011 y $R^{2}=$ 0.887 en 2012). La duración de la lactancia, a partir de las observaciones de 2012, se estimó que fue de 22.65 días. En ambos años (2011 y 2012), la duración de la temporada de cría fue de 9 semanas aproximadamente, de mediados de febrero a mediados de abril (Tabla 1, Fig. 2). La fecha media de nacimientos se produjo a principios de marzo y el máximo número de crías ocurrió a mediados de marzo (Tabla 1, Fig. 2). Se estimó que el número total de crías fue 34 en 2011 y 35 en 2012 (ver regresiones lineales en Fig. 2).

\section{Temporalidad y progresión de la muda de focas de puerto}

La distribución temporal de la frecuencia relativa acumulada del número de individuos en las etapas de premuda $\mathrm{C}$ y muda se ajustó satisfactoriamente al modelo logístico $\left(R^{2}=0.995\right.$ para premuda $\mathrm{C}$ y $R^{2}=0.998$ para la etapa de muda) (Fig. 3). Se estimó que la etapa de premuda $\mathrm{C}$ tuvo una duración de 15 semanas; comenzó a finales de marzo y concluyó a principios de julio (Tabla 2). La etapa de muda tuvo una duración de 11 semanas, aproximadamente, e inició a finales de abril y terminó a mediados de julio. La distribución temporal de la proporción de individuos en premuda $\mathrm{C}$ y en muda se ajustó a un polinomio de grado 5 y a uno de grado 3 , respectivamente $\left(R^{2}=0.803\right.$ para premuda C y $R^{2}=0.737$ para la etapa de muda). La proporción máxima de individuos en premuda $\mathrm{C}$ se estimó que fue el 5 de mayo $(63 \%)$ y en la etapa de muda, el 10 de junio (48\%).

Se encontraron diferencias significativas entre los 2 patrones de progresión de la muda $(U=37, P<0.001)$. De los individuos que se pudieron clasificar por día en alguno de los patrones, en promedio el 19\% siguieron el patrón de muda de las aletas y la cabeza al tronco y el $81 \%$ siguieron el patrón de muda inverso.

\section{Variación temporal de abundancia de focas de puerto en tierra}

En cuanto al número total de individuos, se encontró que durante la temporada de cría y de muda se observó a más del $50 \%$ de los individuos en tierra. En el caso de los individuos adultos e inmaduros, sólo durante la temporada de muda se observó a más del $50 \%$ en tierra (Fig. 4).

\section{DisCuSIÓN}

\section{Temporalidad de los nacimientos de focas de puerto}

La temporada de cría de $P$. v. richardii en el EPB tuvo lugar de mediados de febrero a mediados de abril, y coincide 
Fernández-Martín et al.: Timing of pupping and molting of the Pacific harbor seal
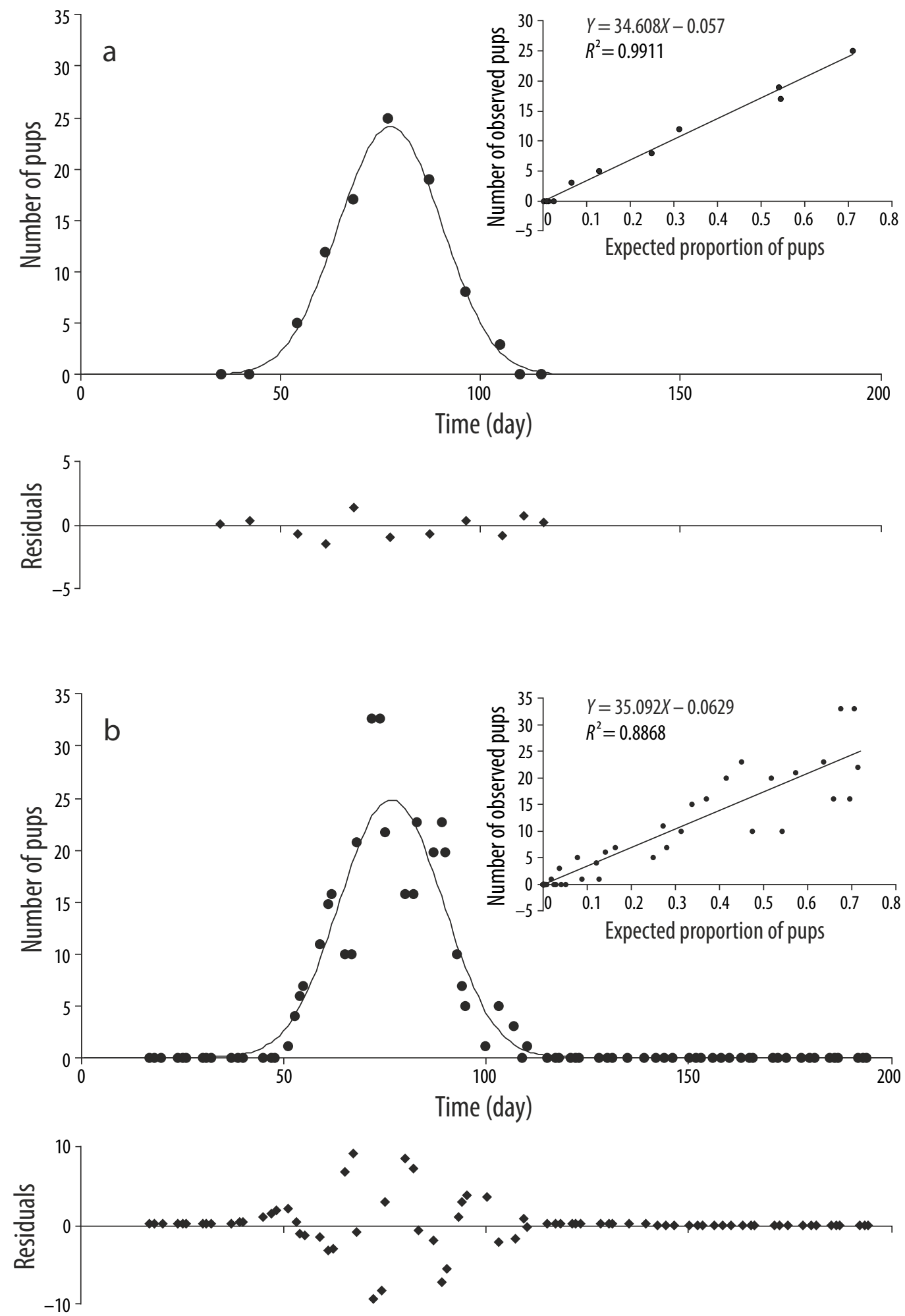

Figure 2. Temporal distribution fit with the Rothery and McCann (1987) model ( - ) for counts (•) of the harbor seal, Phoca vitulina richardii, pups observed during the 2011 (a) and 2012 (b) pupping seasons at Punta Banda Estuary. Residuals are shown at the bottom and the regression model is shown on the upper right-hand side. Day $1=1$ January.

Figura 2. Distribución temporal ajustada con el modelo de Rothery y McCann (1987) (-) para los conteos (•) de las crías de foca de puerto, Phoca vitulina richardii, observadas durante la temporada de cría de 2011 (a) y de 2012 (b) en el estero de Punta Banda. Los residuales se muestran en la parte inferior y el modelo de regresión se muestra en la parte superior derecha. El día 1 representa el día 1 de enero. 
Table 1. Timing of pupping of the harbor seal, Phoca vitulina richardii, at Punta Banda Estuary in 2011 and 2012, estimated using Rothery and McCann's (1987) model. Day 1 = 1 January. The pupping season starts when the first newborn pup is observed. The end of pupping season is estimated to be when all pups have been weaned.

Tabla 1. Temporalidad de los nacimientos de la foca de puerto, Phoca vitulina richardii, en el estero de Punta Banda en 2011 y 2012 , estimada a partir del modelo de Rothery y McCann (1987). El día 1 representa el día 1 de enero. La temporada de cría empieza cuando se observa la primera cría recién nacida. El fin de la temporada de cría se estima cuando todas las crías han sido destetadas.

\begin{tabular}{lcc}
\hline & 2011 & 2012 \\
\hline Mean pupping date $(\mu)$ & 7 March (day 66) & 5 March (day 65) \\
Standard deviation $(\sigma)$ & 10.72 & 10.52 \\
Pupping season start date & 15 February (day 46) & 15 February (day 46) \\
Pupping season end date & 20 April (day 110) & 17 April (day 108) \\
Duration of the pupping season & 9.14 weeks (64 days) & 8.86 weeks (62 days) \\
Peak pup count date & 18 March (day 77) & 17 March (day 77) \\
Total pups born $\left(N_{T}\right)$ & 34 & 35 \\
Duration of the nursing period $(L)$ & - & 22.65 days \\
\hline
\end{tabular}

Compared to more northerly locations, birthing at PBE initiated earlier, in agreement with the latitudinal cline described by Temte et al. (1991). Based on the linear regression proposed by Temte et al. (1991), in terms of latitude for the colonies from Mexico to Washington, the mean pupping date should be 29 March in PBE; however, it was 5 March, that is, 24 days earlier. Although it falls within the lower limit of the $95 \%$ confidence interval (27 February to 28 April), this interval is too wide. If, however, the mean pupping date for $\operatorname{PBE}\left(31.77^{\circ} \mathrm{N}\right)$ is compared with that for La Jolla, California $\left(32.85^{\circ} \mathrm{N}\right)$, which was calculated using data published by $\mathrm{La}$ Jolla Friends of the Seals (2012), birthing at that site in 2012 occurred 12 days earlier (22 February) than at PBE. In this case the latitudinal gradient is not apparently met, as the mean pupping date should be 4.1 days later for each degree of latitude northward (Temte et al. 1991). Moreover, there seems to be a time lag between the pupping season at PBE and nearby Todos Santos Sur Island, Baja California $\left(31.8^{\circ} \mathrm{N}\right)$, since in 2013 the pupping season at PBE lasted at least 11 days longer than on the island (unpublished data). As both sites are located practically at the same latitude and the seals are exposed to the same photoperiod, it would be reasonable to assume that the pupping season would occur at the same time at both locations. The above, therefore, seems to indicate that the PBE colony is reproductively isolated from the island's colony. Such is the case of harbor seals inhabiting Puget Sound, Washington, where differences in the pupping seasons among close colonies have been attributed to genetic differences among populations (Huber et al. 2010). Temte (1994) observed that each population of harbor seals responds to a specific photoperiod that triggers the reactivation of the blastocyst and controls the moment of implantation. In the Pacific harbor seal, blastocyst implantation occurs 283 days (range: 274-291 days) before birth (Temte 1994). Another factor supporting the hypothesis that the PBE colony con el periodo de tiempo en que se realizaron las observaciones puntuales de crías en 1983, 1984 y 1990 (PadillaVillavicencio 1990, Loya-Salinas et al. 1992). Además, la fecha media de nacimientos estimada para la temporada de 2011 y la de 2012 sólo varió por un día, de forma que se reflejó la alta sincronización que presentan los nacimientos de la foca de puerto año tras año en una zona determinada (Temte 1991). Sin embargo, existe un registro de 13 crías a principios de mayo de 1982 en el EPB (Padilla-Villavicencio 1990). Es posible que éstas pudieron haber sido crías destetadas o la temporada de cría se pudo haber atrasado debido a las condiciones ambientales, como por ejemplo, una disminución de la disponibilidad de alimento el año anterior al conteo (Bohorquez 2001, Jemison y Kelly 2001). Esta última hipótesis es menos probable debido a que en 1981 los valores del Índice Oceánico de El Niño no presentaron anomalías (CPC 2015). También existe un registro de 2 crías a finales de enero de 1984 (Padilla-Villavicencio 1990), pero estas crías pudieron haber sido prematuras.

Los nacimientos en el EPB comenzaron en fechas más tempranas, si se compara con las localidades más norteñas, por lo que parece cumplirse la clina latitudinal descrita por Temte et al. (1991). Con base en la regresión lineal propuesta por Temte et al. (1991), en función de la latitud para las colonias de México a Washington, la fecha media de nacimientos debería ser el 29 de marzo en el EPB; sin embargo, ocurrió el 5 de marzo, es decir, 24 días antes. Aunque este día se encuentra en el límite inferior del intervalo de confianza del $95 \%$ ( 27 de febrero a 28 de abril), este intervalo es demasiado amplio. En cambio, si se compara la fecha media de nacimientos para el EPB $\left(31.77^{\circ} \mathrm{N}\right)$ con aquella para La Jolla, California $\left(32.85^{\circ} \mathrm{N}\right)$, que se calculó a partir de datos publicados por La Jolla Friends of the Seals (2012), se obtiene que los nacimientos en ese sitio ocurrieron 12 días antes en 2012 (22 de febrero) que en el EPB. No parece cumplirse en este 


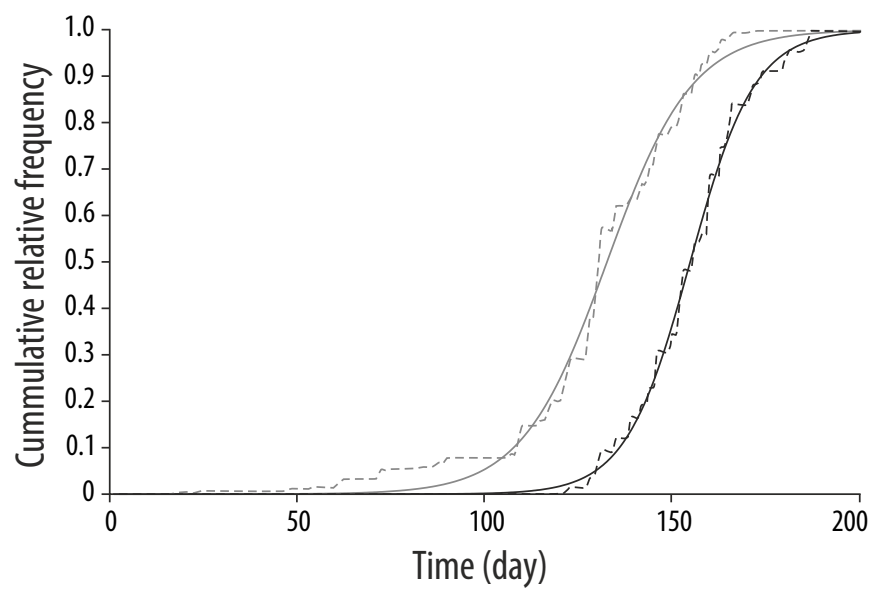

Figure 3. Logistic model for the cummulative frequency of the number of individuals in the late premolt stage (premolt $\mathrm{C}$, continuous grey line) and the molt stage (continuous black line) of the harbor seal, Phoca vitulina richardii, during 2012 at Punta Banda Estuary. The cummulative relative frequencies of the premolt $\mathrm{C}$ (dashed grey line) and molt (dashed black line) stages are also shown. Day $1=1$ January.

Figura 3. Modelo logístico de la frecuencia acumulada del número de individuos en la etapa tardía de premuda (premuda $\mathrm{C}$, línea continua gris) y la etapa de muda (línea continua negra) de la foca de puerto, Phoca vitulina richardii, en 2012 en el estero de Punta Banda. También se muestra la frecuencia relativa acumulada de la premuda $\mathrm{C}$ (línea discontinua gris) y la muda (línea discontinua negra). El día 1 representa el día 1 de enero.

may be reproductively isolated is that the critical photoperiod which this colony responds to (between 13.88 and $14.14 \mathrm{~h}$ of light per day) does not coincide with the photoperiod reported for the harbor seal from Washington to Mexico (14.3 h of light per day; Temte 1994).

The pupping season was estimated to last approximately 9 weeks, one week more than the 6-8 weeks reported for the species (Bigg 1981). A total of 35 pups were estimated in 2012, which coincides with our observed data, since the maximum number of pups counted was 33, and 2 had died before the count. The number of pups estimated was similar in both years (34 in 2011 and 35 in 2012), so pup production appears to have been constant at PBE. The nursing period was caso el gradiente latitudinal, que describe que la fecha media de nacimientos se produciría 4.1 días más tarde por grado de latitud hacia el norte (Temte et al. 1991). Además, parece haber un desfase entre la temporada de cría en el EPB y la temporada en la isla Todos Santos Sur, Baja California $\left(31.8^{\circ} \mathrm{N}\right)$, ya que en 2013 la temporada de cría en el EPB continuó al menos 11 días más después de que la temporada hubiera finalizado en la isla Todos Santos (datos no publicados). En este caso se esperaría que en ambas zonas la temporada de nacimientos se produjera al mismo tiempo, debido a que se encuentran prácticamente a la misma latitud $\mathrm{y}$, por tanto, están expuestas a las mismas horas de luz al día (fotoperiodo). Todo lo anterior podría indicar que la colonia de focas del EPB está reproductivamente aislada de la colonia de la isla. Este es el caso de las focas de Puget Sound, Washington, donde las diferencias en la temporalidad de los nacimientos entre colonias cercanas fueron atribuidas a diferencias genéticas importantes entre poblaciones (Huber et al. 2010). Se ha determinado que cada población de foca de puerto responde a un fotoperiodo específico que señala la reactivación del blastocisto y controla el momento de la implantación (Temte 1994). En la foca de puerto del Pacífico, la implantación del blastocisto se produce 283 días (rango: 274-291) antes del nacimiento (Temte 1994). Otro factor que podría apoyar que la colonia del EPB está aislada reproductivamente es que el fotoperiodo crítico al que responde esta colonia (entre 13.88 y 14.14 h de luz al día) no coincide con el fotoperiodo reportado para la foca de puerto de Washington a México (14.3 h de luz al día; Temte 1994).

Se estimó una duración de la temporada de cría de aproximadamente 9 semanas, 1 semana más que las 6 a 8 semanas reportadas para la especie (Bigg 1981). El número total de crías estimadas en 2012 fue de 35 crías, que coincide con los datos observados, ya que el máximo conteo de crías fue de 33 crías, y 2 crías habían muerto antes de este conteo. Debido a que el número de crías estimado fue semejante en ambos años (34 en 2011 y 35 en 2012), podría suponerse que la producción de crías se mantuvo constante en el EPB. Se estimó una duración de la lactancia de 3 semanas, que es menor que las 4 a 6 semanas reportadas para las colonias de P. v. richardii en Washington (Newby 1973) y en el sur de Columbia Británica (Cottrell et al. 2002). Esto puede deberse

Table 2. Timing of the molt of the harbor seal, Phoca vitulina richardii, at Punta Banda Estuary, estimated using data obtained in 2012. Day $1=1$ January. The end date is defined as when the proportion of individuals is $>0.99$.

Tabla 2. Temporalidad de la muda de la foca de puerto, Phoca vitulina richardii, en el estero de Punta Banda, estimada con datos obtenidos en 2012. El día 1 representa el día 1 de enero. El final de la temporada se estima que es cuando la proporción de individuos es $>0.99$.

\begin{tabular}{lcc}
\hline & Late premolt stage & Molt stage \\
\hline Stage start date & 21 March (day 81) & 25 April (day 116) \\
Stage end date & 3 July (day 185) & 13 July (day 195) \\
Stage duration & 14.86 weeks (104 days) & 11.29 weeks (79 days) \\
Date with peak proportion of individuals in each stage & 5 May (day 126) & 10 June (day 162) \\
\hline
\end{tabular}



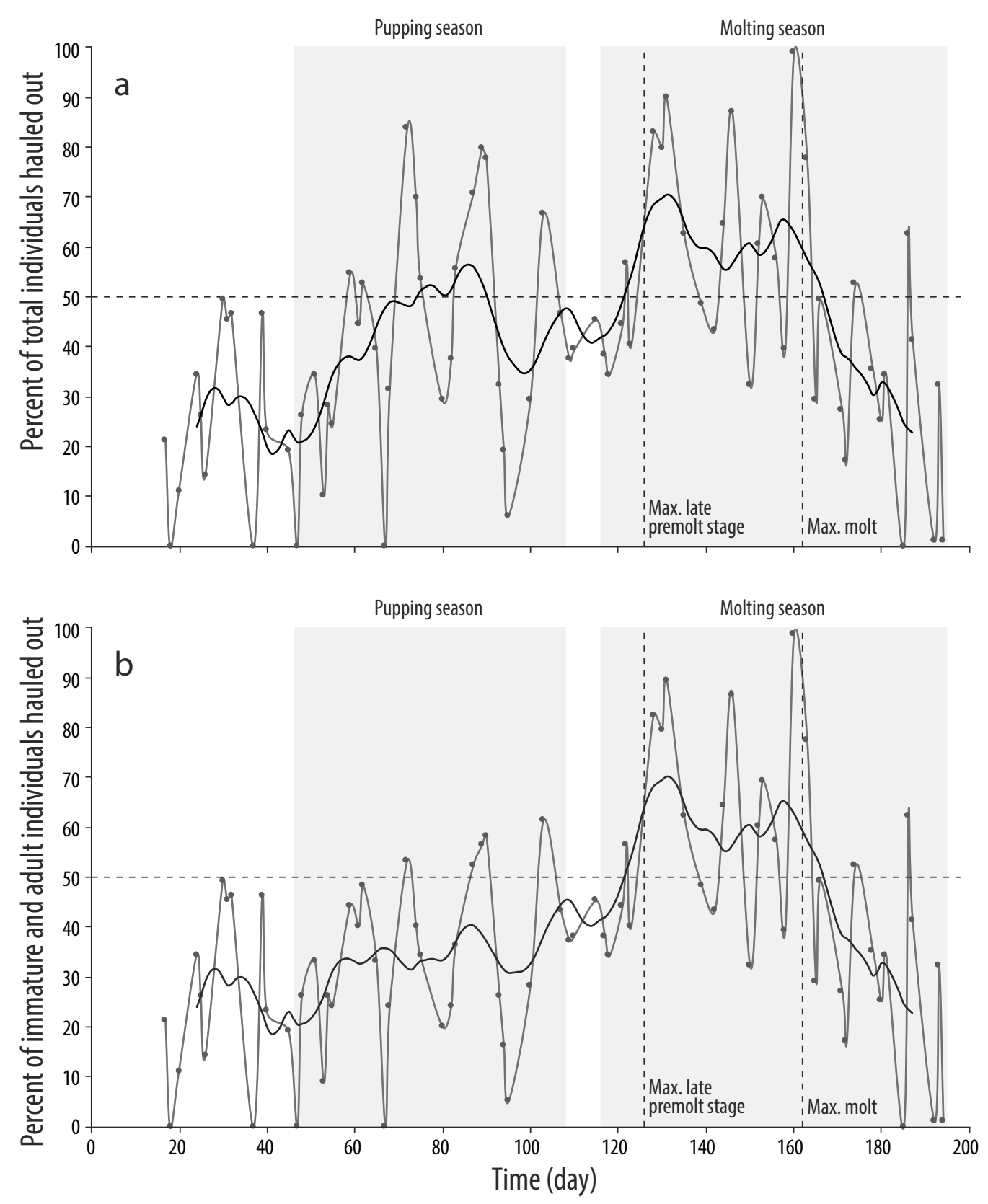

Figure 4. Percentage of total individuals (a) and of immature and adult individuals (b) of the harbor seal, Phoca vitulina richardii, hauled out during the 2012 observation period at Punta Banda Estuary. Moving average (-); percentage of hauled-out individuals during each count $(\bullet)$. Day $1=1$ January.

Figura 4. Porcentaje del total de individuos (a) y de individuos inmaduros y adultos (b) de la foca de puerto, Phoca vitulina richardii, en tierra a lo largo del periodo de observación de 2012 en el estero de Punta Banda. Media móvil (-); porcentaje de individuos de la colonia en tierra por conteo $(\bullet)$. El día 1 representa el día 1 de enero.

estimated to last 3 weeks, less than the 4-6 weeks reported for $P$. v. richardii colonies in Washington (Newby 1973) and southern British Columbia (Cottrell et al. 2002). This can be due to the anthropogenic disturbance experienced by the PBE seals, as observed during the field work. Disturbances can increase the rate of pup abandonment (Jemison and Kelly 2001), which is reflected in a shorter nursing period. Food availability before and after the pupping season may also al disturbio por presencia humana al que están sometidas las focas en el EPB, como se pudo observar en el trabajo de campo. El disturbio puede provocar un aumento en la tasa de abandono de las crías (Jemison y Kelly 2001), lo que se refleja en una disminución del tiempo de lactancia. La disponibilidad de alimento antes y durante la temporada de cría también puede influir en la duración de la lactancia (Jemison y Kelly 2001). 
influence the duration of the nursing period (Jemison and Kelly 2001).

\section{Timing and progression of the molt of harbor seals}

The molting period of $P$. v. richardii at PBE occurred from the end of April to mid-July, earlier than that reported for other more northerly locations, including California (May to June; Stewart and Yochem 1994), Oregon (July to September; Brown and Mate 1983), Washington and Canada (August to October; Stutz 1967), and Alaska (July to September; Daniel et al. 2003). The molt timing appears to follow a south-to-north latitudinal cline, probably related to a response to photoperiod (Mo et al. 2000) and to the timing of the breeding season, which also shows a latitudinal cline (Temte et al. 1991), since in the case of females and adult males, the molt is inhibited by sexual hormones (Thompson and Rothery 1987, Daniel et al. 2003). The premolt C stage occurs from late March to early July at PBE, but on Tugidak Island (Alaska) it ends in late August or early September (Daniel et al. 2003), which also indicates a latitudinal cline.

The reverse molt pattern (head and flippers are the last areas to molt) predominated at PBE. At other more northerly locations of the distribution of $P$. v. richardii, including Canada (Stutz 1967) and Alaska (Ashwell-Erickson et al. 1986, Daniel et al. 2003), the molt pattern where shedding of hair occurs first on the head and flippers and progresses over the rest of the body is the most commonly recognized. In southwestern Ireland, Cronin et al. (2014) observed that a large proportion (48\%) of individuals of the subspecies P. $v$. vitulina exhibited the reverse molt pattern. In other species of phocids, the differences in molt progression has been linked to the nutritional status of the individuals (Lydersen et al. 2000). In the present study, the seals exhibiting the reverse molt pattern did not appear to have poor body condition relative to the seals exhibiting the other pattern. A possible explanation for the predominance of the reverse molt pattern at PBE can be differences in ambient temperature. Mauck et al. (2003) observed, using infrared thermography, that when the seals are hauled out, the temperature in the area of the head, neck, and hind flippers begins to rise when ambient temperatures are low $\left(5-12^{\circ} \mathrm{C}\right)$. Though the same occurs at high ambient temperatures, the areas of heat loss extend towards the torso and, if the individuals remain out of water long enough, the high-temperature areas on the torso exceed those on the head, neck, and hind flippers $\left(32-36^{\circ} \mathrm{C}\right.$; Mauck et al. 2003). As the epidermis needs high temperatures for follicular regeneration (Boily 1995), the differences in the ambient temperature of the colonies may determine the progression of the molt. That is, at low latitudes, where ambient temperatures are higher, the molt initiates on the torso and progresses to the periphery (head and flippers; reverse molt pattern), but at high latitudes, where ambient temperatures are cooler, the head and flippers are the first areas to molt.

\section{Temporalidad y progresión de la muda de focas de puerto}

La temporada de muda de $P$. v. richardii en el EPB se presenta de finales de abril a mediados de julio, antes que lo reportado para otros lugares localizados más al norte, como California (de mayo a junio; Stewart y Yochem 1994), Oregón (de julio a septiembre; Brown y Mate 1983), Washington y Canadá (de agosto a octubre; Stutz 1967), y Alaska (de julio a septiembre; Daniel et al. 2003). La temporada de muda parece seguir una clina latitudinal de sur a norte, lo que podría deberse a una respuesta al fotoperiodo (Mo et al. 2000) y a la conexión con la temporada reproductiva, la cual también presenta una clina latitudinal (Temte et al. 1991), ya que la muda en las hembras y los machos adultos se encuentra inhibida por hormonas sexuales (Thompson y Rothery 1987, Daniel et al. 2003). La etapa de premuda $\mathrm{C}$ en el EPB comienza a finales de marzo y concluye a principios de julio, pero en la isla Tugidak (Alaska) termina entre finales de agosto y principios de septiembre (Daniel et al. 2003), por lo que en esta etapa también se aprecia el gradiente latitudinal.

En el EPB, el patrón de muda inverso es el predominante. Sin embargo, en otros lugares de la distribución de $P$. v. richardii situados a latitudes más altas, como Canadá (Stutz 1967) y Alaska (Ashwell-Erickson et al. 1986, Daniel et al. 2003), el patrón de muda de las aletas y la cabeza al tronco es el predominante. Este último patrón también se ha observado en la subespecie P. v. vitulina del suroeste de Irlanda, aunque en esta zona se ha observado una mayor proporción de individuos que presentan el patrón de muda inverso (48\%, Cronin et al. 2014). En otras especies de fócidos se piensa que esta diferencia en la progresión de la muda podría deberse al estado nutricional de los individuos (Lydersen et al. 2000). En este estudio no se vio que las focas que presentaban el patrón de muda inverso tuvieran una mala condición corporal en comparación con las que presentaban el otro patrón. Una posible explicación sobre la predominancia del patrón de muda inverso en el EPB puede estar relacionada con diferencias en la temperatura ambiental. Se ha observado, por medio de termografía infrarroja, que al encontrarse en tierra, las focas comienzan a elevar su temperatura en la región de la cabeza, cuello y aletas posteriores cuando la temperatura ambiental es baja $\left(5-12{ }^{\circ} \mathrm{C}\right.$; Mauck et al. 2003). A pesar de que ocurre lo mismo a altas temperaturas ambientales, las zonas de liberación de calor se extienden hacia el cuerpo y, si las focas permanecen suficiente tiempo fuera del agua, las zonas de alta temperatura en el tronco del cuerpo superan a las de la cabeza, el cuello y las aletas (32-36 ${ }^{\circ} \mathrm{C}$; Mauck et al. 2003). Debido a que la epidermis necesita de una alta temperatura para la regeneración folicular (Boily 1995), las diferencias en la temperatura ambiental entre las colonias podrían determinar la progresión de la muda. Es decir, las latitudes bajas, donde las temperaturas ambientales son altas, favorecerían un patrón de muda del tronco hacia la periferia (cabeza y aletas; patrón de muda 


\section{Temporal variation in the abundance of harbor seals on land}

The highest numbers of $P$. v. richardii on land have been recorded during the pupping and molting seasons (Brown and Mate 1983, Jemison and Kelly 2001). Our findings are in agreement; however, when the number of hauled-out adult and immature individuals (weaned pups, yearlings, and subadults) is analyzed, only during the molting season is more than $50 \%$ of the colony found on land. This indicates that the high abundance of individuals on land during the pupping season at PBE is due to the pups.

At PBE, as in southern California (Stewart and Yochem 1994) and Alaska (Daniel et al. 2003), the highest numbers of adult and immature $P$. $v$. richardii were recorded during the molting season. This is because individuals that are about to molt spend more time on land (Daniel et al. 2003). Individuals likely haul out as a strategy to conserve energy, in view of the amount of energy required during the molt period to maintain the high temperature needed by the epidermis to carry out this process (Boily 1995), and this is better achieved on land (Feltz and Fay 1966). After completing the molt, the individuals once again spend more time in the water feeding (Stewart and Yochem 1994), which would explain the decrease in abundance at the end of the molting season. Moreover, the highest percentage of individuals on land occurs between the peak proportion of individuals in premolt $\mathrm{C}$ stage and the peak proportion of individuals in the molt stage. Therefore, it would be advisable to conduct surveys aiming to estimate the abundance of this population during this period of time (between 5 May and 10 June). Counts should preferably be conducted during low tide when more seals tend to be hauled out and, in the case of PBE, when the low tide coincides with the early morning hours and there is less human presence on the beaches.

In summary, at PBE, the pupping season of $P$. v. richardii begins in mid-February and ends in mid-April, and the molting season begins at the end of April and ends in mid-July. The reverse molt pattern (head and flippers are the last areas to shed) predominated. The number of hauled-out adult and immature individuals was highest during the molt period; hence, the best time to perform counts and estimate the abundance of $P$. $v$. richardii at PBE is from early May to early June.

\section{ACKNOWLEDGMENTS}

This study was financed by CICESE. The first author acknowledges receipt of a postgraduate scholarship from the National Council for Science and Technology (CONACYT, Mexico). Permits were provided by the Mexican Ministry of Environment and Natural Resources (SEMARNAT, SGPA/ DGVS/03550/10 and SGPA/DGVS/03551/11). We thank Eric Mellink, Benjamín Barón, and an anonymous reviewer inverso), y las latitudes altas, donde las temperaturas ambientales son bajas, favorecerían un patrón de muda de la cabeza y las aletas hacia el tronco.

\section{Variación temporal de abundancia de focas de puerto en tierra}

Las máximas abundancias de $P$. $v$. richardii en tierra se han encontrado durante las temporadas de cría y de muda (Brown y Mate 1983, Jemison y Kelly 2001), lo cual parece coincidir con este estudio en cuanto al número total de individuos en tierra en estas temporadas. Sin embargo, al examinar el número de individuos adultos e inmaduros (destetados, añeros y subadultos) en tierra, es sólo durante la temporada de muda cuando se puede encontrar a más del 50\% de la colonia en tierra. Esto indica que la alta abundancia de individuos en tierra durante la temporada de cría en el EPB se debe precisamente a las crías.

En el EPB, el periodo de mayor abundancia de individuos adultos e inmaduros de $P$. $v$. richardii fue la temporada de muda, al igual que lo reportado para el sur de California (Stewart y Yochem 1994) y Alaska (Daniel et al. 2003). Esto se debe a que los individuos que van a mudar pasan más tiempo en tierra (Daniel et al. 2003). Los individuos posiblemente utilizan su estancia en tierra como una estrategia para conservar energía, debido a los gastos energéticos requeridos durante la muda para mantener la alta temperatura que necesita la epidermis al realizar este proceso (Boily 1995), la cual se puede alcanzar mejor estando en tierra (Feltz y Fay 1966). Después de completar la muda, los individuos vuelven a pasar más tiempo en el agua alimentándose (Stewart y Yochem 1994), lo que puede explicar la tendencia de la abundancia a disminuir al final de la temporada de muda. Además, el mayor porcentaje de individuos en tierra se encuentra entre la máxima proporción de individuos en premuda $\mathrm{C}$ y la máxima proporción de individuos en muda. Por lo tanto, si se quiere estimar la abundancia de esta población, sería recomendable realizar los conteos en este periodo de tiempo (del 5 de mayo al 10 de junio). También se debe considerar hacer los conteos durante la marea baja, que es cuando más focas tienden a estar fuera del agua, y, en el EPB, en los días en los que la marea baja coincida con las primeras horas de luz, cuando hay menos presencia humana en las playas.

En resumen, en este trabajo se determinó que la temporada de cría de $P$. $v$. richardii en el EPB comienza a mediados de febrero y finaliza a mediados de abril, mientras que la temporada de muda inicia a finales de abril y termina a mediados de julio. El patrón de muda predominante fue el inverso, de tronco a cabeza y aletas. La mayor abundancia de individuos adultos e inmaduros en tierra se encontró durante la temporada de muda, de forma que el momento óptimo para realizar conteos y estimar la abundancia de $P$. $v$. richardii en el EPB es de principios de mayo a principios de junio. 
for their valuable comments that helped to improve this work, as well as all those who participated in the field work, especially Eulogio López and Ivonne Martínez.

English translation by Christine Harris.

\section{REFERENCES}

Ashwell-Erickson S, Fay FH, Elsner R, Wartzok D. 1986. Metabolic and hormonal correlates of molting and regeneration of pelage in Alaskan harbor and spotted seals (Phoca vitulina and Phoca largha). Can. J. Zool. 64(5): 1086-1094. http://dx.doi.org/10.1139/z86-163

Bigg MA. 1981. Harbour seal: Phoca vitulina and P. largha. In: Ridgway SH, Harrison, RJ (eds.), Handbook of Marine Mammals. Vol. 2. Seals. Academic Press, London, pp. 1-27.

Bohorquez AS. 2001. Pupping phenology and haul out patterns of harbor seals (Phoca vitulina richardii) in San Francisco, California. MSc thesis, San Francisco State University, San Francisco, California, USA, 75 pp.

Boily P. 1995. Theoretical heat flux in water and habitat selection of phocid seals and beluga whales during the annual molt. J. Theor. Biol. 172(3): 235-244.

http://dx.doi.org/10.1006/jtbi.1995.0020

Bonnes DJ, Bowen WD, Buhleier BM, Marshall GJ. 2006. Mating tactics and mating system of an aquatic mating pinniped: The harbor seal, Phoca vitulina. Behav. Ecol. Sociobiol. 61(1): $119-130$ http://dx.doi.org/10.1007/s00265-006-0242-9

Brown RF, Mate BR. 1983. Abundance, movements, and feeding habits of harbor seals, Phoca vitulina, at Netarts and Tillamook bays, Oregon. Fish. Bull. 81(2): 291-301.

Committee on Taxonomy. 2016. List of marine mammal species and subspecies. Society for Marine Mammalogy [cited 22 August 2016]. Available from: https://www.marinemammalscience.org/ species-information/list-marine-mammal-species-subspecies/.

Cottrell PE, Jeffries S, Beck B, Ross PS. 2002. Growth and development in free-ranging harbor seal (Phoca vitulina) pups from southern British Columbia, Canada. Mar. Mammal Sci. 18(3): 721-733. http://dx.doi.org/10.1111/j.1748-7692.2002.tb01069.x

[CPC] Climate Prediction Center. 2015. Historical El Niño/La Niña episodes (1950-present). National Oceanic Atmospheric Administration/National Weather Service [cited 24 May 2016]. Available from: http://www.cpc.noaa.gov/products/ analysis_monitoring/ensostuff/ensoyears.shtml.

Cronin M, Gregory S, Rogan E. 2014. Moulting phenology of the harbour seal in south-west Ireland. J. Mar. Biol. Assoc. UK 94(06): 1079-1086. http://dx.doi.org/10.1017/S0025315413000106

Daniel RG, Jemison LA, Pendleton GW, Crowley SM. 2003. Molting phenology of harbor seals on Tugidak Island, Alaska. Mar. Mammal Sci. 19(1): 128-140.

http://dx.doi.org/10.1111/j.1748-7692.2003.tb01097.x

Feltz ET, Fay FH. 1966. Thermal requirements in vitro of epidermal cells from seals. Cryobiology 3(3): 261-264. http://dx.doi.org/10.1016/S0011-2240(66)80020-2

García-Aguilar MC. 2004. Breeding biology of the northern elephant seal (Mirounga angustirostris) at the Isla San Benito del Oeste, Eastern Pacific, Mexico. Aquat. Mamm. 30(2): 289-295.

http://dx.doi.org/10.1578/AM.30.2.2004.289

\section{Agradecimientos}

El CICESE financió esta investigación y el Consejo Nacional de Ciencia y Tecnología (CONACYT, México) otorgó una beca de maestría a la primera autora. La Dirección General de Vida Silvestre de la Secretaría de Medio Ambiente y Recursos Naturales (SEMARNAT) otorgó las autorizaciones SGPA/DGVS/03550/10 y /03551/11. Eric Mellink y Benjamín Barón ayudaron a mejorar este trabajo, así como los comentarios de un revisor anónimo. Agradecemos a todas las personas que colaboraron en el trabajo de campo, especialmente a Eulogio López e Ivonne Martínez.

Härkönen T, Harding KC. 2001. Spatial structure of harbour seal populations and the implications thereof. Can. J. Zool. 79(12): 2115-2127. http://dx.doi.org/10.1139/z01-172

Huber HR, Jeffries SJ, Brown RF, DeLong RL, VanBlaricom G. 2001. Correcting aerial counts of harbor seal (Phoca vitulina richardsi) in Washington and Oregon. Mar. Mammal Sci. 17(2): 276-293. http://dx.doi.org/10.1111/j.1748-7692.2001.tb01271.x

Huber HR, Jeffries SJ, Lambourn DM, Dickerson BR. 2010. Population substructure of harbor seals (Phoca vitulina richardsi) in Washington State using mtDNA. Can. J. Zool. 88(3): 280-288. http://dx.doi.org/10.1139/Z09-141

Jemison LA, Kelly B. 2001. Pupping phenology and demography of harbor seals (Phoca vitulina richardsi) on Tugidak Island, Alaska. Mar. Mammal Sci. 17(3): 585-600. http://dx.doi.org/10.1111/j.1748-7692.2001.tb01006.x

Jemison LA, Pendleton GW, Wilson CA, Small RJ. 2006. Long-term trends in harbor seal numbers at Tugidak Island and Nanvak Bay, Alaska. Mar. Mammal Sci. 22(2): 339-360. http://dx.doi.org/10.1111/j.1748-7692.2006.00021.x

La Jolla Friends of the Seals. 2012. Pup news 2012 [online]. Seal Conservancy [cited 22 August 2016]. San Diego. Available from: http://sealconservancy.org/pup-news-2012/.

Ling JK. 1972. Adaptive functions of vertebrate molting cycles. Am. Zool. 12(1): 77-93. http://dx.doi.org/10.1093/icb/12.1.77

Loya-Salinas DH, Palacios E, González S. 1992. Seasonal abundances of the harbor seal (Phoca vitulina richardsi Gray 1864) at Punta Banda Estuary (B.C., Mexico) = Abundancia estacional de la foca de bahía (Phoca vitulina richardsi Gray 1864) en el Estero de Punta Banda (B.C., México). Cienc. Mar. 18(3): 57-70.

Lubinsky-Jinich D, Schramm Y, Heckel G. The Pacific harbor seal's (Phoca vitulina richardii) breeding colonies in Mexico: Abundance and distribution. Aquat. Mamm. (in press).

Lydersen C, Kovacs KM, Hammill MO. 2000. Reversed molting pattern in starveling gray (Halichoerus grypus) and harp (Phoca groenlandica) seal pups. Mar. Mammal Sci. 16(2): 489-493. http://dx.doi.org/10.1111/j.1748-7692.2000.tb00941.x

Maravilla-Chávez M, Lowry M. 1996. Censos de pinnípedos en islas de la costa occidental de la península de Baja California, México (julio/agosto 1992). Cienc. Pesq. 13: 73-77.

Mauck B, Bilgmann K, Jones DD, Eysel U, Dehnhardt G. 2003. Thermal windows on the trunk of hauled-out seals: Hot spots for thermoregulatory evaporation? J. Exp. Biol. 206: 1727-1738. http://dx.doi.org/10.1242/jeb.00348 
Mo G, Gili C, Ferrando P. 2000. Do photoperiod and temperature influence the molt cycle of Phoca vitulina in captivity? Mar. Mammal Sci. 16(3): 570-577.

http://dx.doi.org/10.1111/j.1748-7692.2000.tb00952.x

Newby TC. 1973. Observations of the breeding behavior of the harbor seal in the state of Washington. J. Mammal. 54(2): 540-543. http://dx.doi.org/10.2307/1379151

Padilla-Villavicencio AM. 1990. Aspectos biológicos de la foca común (Phoca vitulina richardsi, Gray (1864)) en la costa occidental de Baja California (Carnivora: Phocidae). BSc thesis, Universidad Nacional Autónoma de México, Mexico City, $88 \mathrm{pp}$.

Rothery P, McCann ST. 1987. Estimating pup production of elephant seals at South Georgia. Symp. Zool. Soc. London. 58: 211-223.

Stewart BS, Yochem P. 1994. Ecology of harbor seals in the Southern California Bight. In: Halvorson WL, Maender GJ (eds), The Fourth California Islands Symposium: Update on the Status of Resources. Santa Barbara Museum of Natural History, Santa Barbara, California, pp. 123-134.

Stutz SS. 1967. Moult in the Pacific harbour seal, Phoca vitulina richardi. J. Fish. Res. Board Can. 24(2): 435-441. http://dx.doi.org/10.1139/f67-035

Suryan RM. 1995. Pupping phenology, disturbance, movements and dive patterns of harbor seal (Phoca vitulina richardsi) off the northern San Juan Islands of Washington. MSc thesis, San Jose State University, San Jose, California, USA, 86 pp.
Suryan RM, Harvey JT. 1998. Tracking harbor seals (Phoca vitulina richardsi) to determine dive behavior, foraging activity, and haul-out site use. Mar. Mammal Sci. 14(2): 361-372. http://dx.doi.org/10.1111/j.1748-7692.1998.tb00728.x

Temte JL. 1991. Precise birth timing in captive harbor seals (Phoca vitulina) and California sea lions (Zalophus californianus). Mar. Mammal Sci. 7(2): 145-156.

http://dx.doi.org/10.1111/j.1748-7692.1991.tb00561.x

Temte JL. 1994. Photoperiod control of birth timing in the harbour seal (Phoca vitulina). J. Zool. 233(3): 369-384. http://dx.doi.org/10.1111/j.1469-7998.1994.tb05271.x

Temte JL, Bigg MA, Wiig O. 1991. Clines revisited: The timing of pupping in the harbour seal (Phoca vitulina). J. Zool. 224(4): $617-632$. http://dx.doi.org/10.1111/j.1469-7998.1991.tb03790.x

Thompson P, Rothery P. 1987. Age and sex differences in the timing of the moult in the common seal, Phoca vitulina. J. Zool. 212(4): 597-603. http://dx.doi.org/10.1111/j.1469-7998.1987.tb05958.x

Tollit DJ, Black AD, Thompson PM, Mackay A, Corpe HM, Wilson B, Van Parijs SM, Grellier K, Parlane S. 1998. Variations in harbour seal Phoca vitulina diet and dive-depths in relation to foraging habitat. J. Zool. 244: 209-222. http://dx.doi.org/10.1111/j.1469-7998.1998.tb00026.x

Zar JH. 2010. Biostatistical Analysis. 5th ed. Pearson Prentice-Hall, Upper Saddle River, NJ, 944 pp.

Received December 2015, accepted August 2016. 